\title{
Physical, mental, emotional and social health status of adolescents and youths in Benghazi, Libya
}

\author{
A.A. Salam, ${ }^{7}$ A.A. Alshekteria, ${ }^{7}$ H.A.A. Mohammed, ${ }^{1}$ N.M. Al Abar, ${ }^{7}$ M.M. Al Jhany and M.F. Al Flah ${ }^{7}$
}

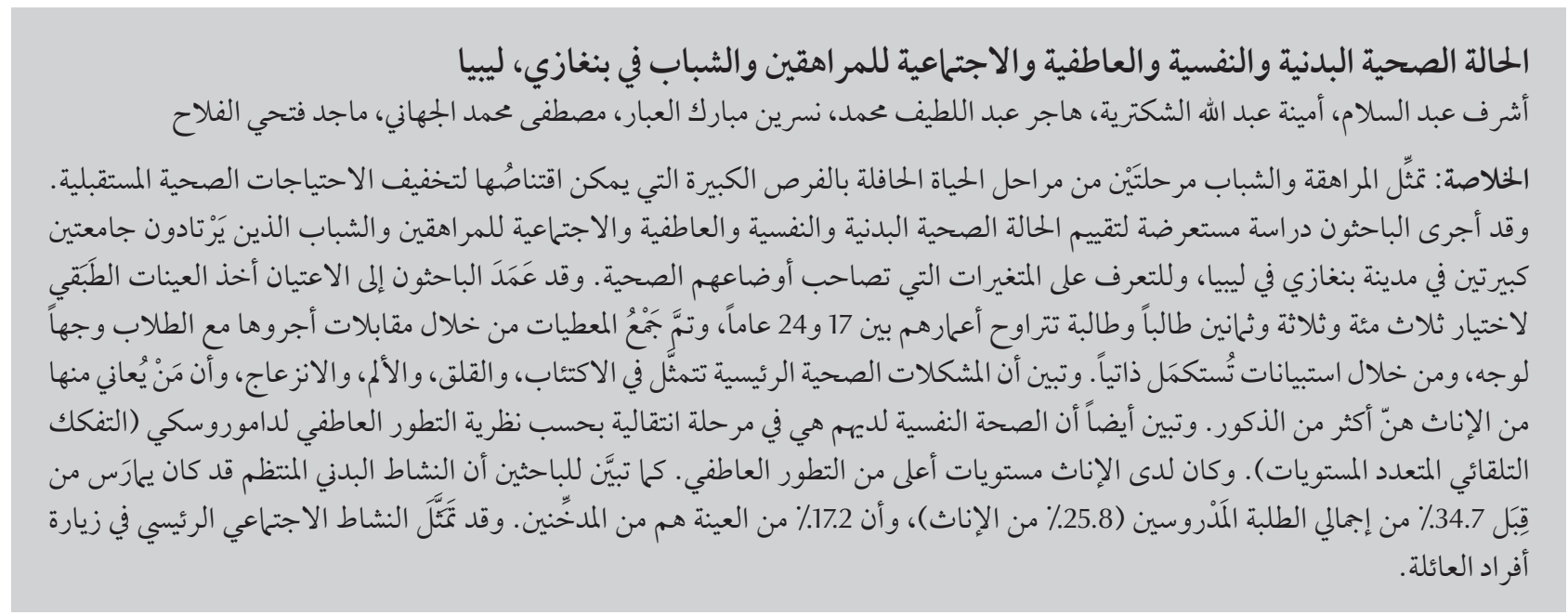

ABSTRACT Adolescence and youth are stages of life that offer great opportunities for reduction of future health needs. A cross-sectional study was carried out to assess the physical, mental, emotional and social health status of adolescents and youths attending 2 large universities in Benghazi city, Libya, and to determine variables associated with their health status. Stratified sampling was used to select 383 students aged 17-24 years and data were collected by face-to-face interview and self-administered questionnaires. Major health problems were depression/anxiety and pain/discomfort, and these were suffered by significantly more females than males. Mental health was at the transitional stage in Dabrowski's emotional development theory (spontaneous multilevel disintegration). Females had higher levels of emotional development. Regular physical activity was practised by $34.7 \%$ overall ( $25.8 \%$ of women) and $17.2 \%$ were smokers. The main social activity was visiting family members.

\section{Santé physique, mentale, psychologique et sociale des adolescents et des jeunes à Benghazi (Libye)}

RÉSUMÉ L'adolescence et la jeunesse sont des époques de la vie qui permettent de réduire de manière importante les futurs besoins en matière de santé. Une étude transversale a été menée pour évaluer la santé physique, mentale, psychologique et sociale des adolescents et des jeunes fréquentant deux grandes universités de la ville de Benghazi (Libye) et pour déterminer les variables associées à leur état de santé. Un échantillonnage stratifié a été utilisé pour sélectionner 383 étudiants âgés de 17 à 24 ans. Des données ont été collectées lors d'une entrevue individuelle et par auto-questionnaires. Les principaux problèmes de santé étaient la dépression/l'anxiété et la douleur/l'inconfort, et ces maux affectaient davantage les filles que les garçons. Leur santé mentale se situait à un stade de transition dans la théorie du développement de Dabrowski (désintégration multiniveaux spontanée). Le développement affectif était plus avancé chez les femmes. Parmi les participants, $34,7 \%$ au total pratiquaient une activité physique (25,8 \% des filles) et 17,2 \% étaient fumeurs. L'activité sociale principale consistait à rendre visite aux membres de la famille. 


\section{Introduction}

Adolescence and youth are stages of life that offer great opportunities for health interventions that focus on influencing healthy attitudes and behaviours [1-6]. The 42nd World Health Assembly recognized the importance of targeting youth as a critical element for the health of future generations through their health actions, choices and behaviours [4]. Attending to the causes of future morbidity aims to reduce the preventable risks due to smoking, drug use, poor diet, low physical activity and factors leading to psychiatric morbidity [1]. Major transitions, such as habit formation, patterns of behaviour and relationships that develop during adolescence affect not only young people's current functioning and opportunities but also the quality of their adult lives [5].

Efforts are being made at national and international levels to address health issues of relevance to adolescent and youth populations and attempting to pave the way for a smooth transition to adulthood through strengthening social and health services to meet adolescents' health and development needs [7]. Little is known about the health status of young people in Libya. The current study was therefore carried out with the aim of assessing the health status (physical, mental, emotional and social) of adolescents and youths in Benghazi city, Libya and to determine variables relevant to their health status.

\section{Methods}

This cross-sectional study of a sample of students from 2 universities - Al Arab Medical and Garyounis (now a single university) - was conducted from January to February 2010.

\section{Sample}

Assuming that age distribution of the Benghazi population was similar to that of Libya as a whole, i.e. $16.5 \%$ aged 17-24 years, the population in Benghazi in this age range was estimated to be 111367 (total population of Benghazi was 674951 as of 2006 census) [8]. Nearly half of population of Benghazi aged 17-24 years were students of these 2 universities. Applying the sample size calculation for a margin of error acceptable as 5\% with confidence level $95 \%$, the minimum required sample size was 383 [9]. Garyounis and Al Arab Medical Universities had a total student population of 42688 . The sample of students was stratified according to faculty and sex and was selected through random sampling interval using random number tables. Respondents were selected from the campus (outside classrooms) during working days.

\section{Tools}

The health status of adolescents and youths in this study was assessed from the perspectives of physical and mental, emotional and social health.

\section{Physical and mental health}

After collecting general socioeconomic data, physical and mental health status was assessed by 3 subscales. The first section covered self-perceived health, diseases in the last year, hospitalizations in the last year (both clinical and psychiatric), current use of medication or undergoing treatments and medical history and a self-rating of general health (4-point scale: excellent, very good, good and poor). The second was respondents' experience of current health complaints (yes/no) and the type. The third was health status today, which was measured using a standardized tool, the health status index questionnaire [10] covering self-perceptions about 5 health indicators: mobility, self-care, usual activities, pain/discomfort and anxiety/ depression), each scored on a 3-point scale. In addition, the respondents were asked to rate their health status today on a scale ranging from $0-100$. The EQ-5D tool [10] was translated into Arabic language for this study.

\section{Emotional health}

Emotional health was assessed and described according to Dabrowski's emotional development scale that describes stages of integration and disintegration $[11,12]$. This scale has 5 levels of positive disintegration of emotions: primary integration; unilevel disintegration; spontaneous multilevel disintegration; organized multilevel disintegration; and secondary integration. This 26 -item scale was divided into 2 parts: emotional functions; and emotional-cognitive functions. The total emotional score was calculated by adding scores of all the 26 items, both emotional functions and emotional cognitive functions [11]. Since the total score ranged from 26-130, it was assumed that a person scoring a maximum of 26 remained at primary integration level; between 27-52, unilevel disintegration level; between 53-78, spontaneous multilevel disintegration level; between 79-104, organized multilevel disintegration level and 105-130, secondary integration level.

\section{Social health}

Respondents' lifestyles were assessed in 4 dimensions: physical activity; eating habits; social activities; and substance use. A tool with open-ended questions was developed to collect relevant information on physical activities, food habits (primary meals, secondary meals, eating out and usual drinks), social activities and habits (smoking, alcohol and drugs).

\section{Data collection}

Data collection was carried out privately after assuring respondents about confidentiality of the information collected. Information on health status and socioeconomic background were collected through face-to-face interviews by researchers at the student campuses of these universities. The Health Status Index and Emotional Development Scale were supplied as self-administered questionnaires. Respondents were 


\begin{tabular}{|c|c|c|c|c|c|c|}
\hline \multirow[t]{2}{*}{ Characteristic } & \multicolumn{2}{|c|}{ Males $(n=154)$} & \multicolumn{2}{|c|}{ Females $(n=229)$} & \multicolumn{2}{|c|}{ Total $(n=383)$} \\
\hline & No. & $\%$ & No. & $\%$ & No. & $\%$ \\
\hline \multicolumn{7}{|l|}{ Age (years) } \\
\hline $17-19$ & 46 & 29.9 & 71 & 31.0 & 117 & 30.5 \\
\hline $20-24$ & 108 & 70.1 & 158 & 69.0 & 266 & 69.5 \\
\hline \multicolumn{7}{|l|}{ Year of study } \\
\hline $1-2$ & 105 & 68.2 & 159 & 69.4 & 264 & 68.9 \\
\hline $3+$ & 49 & 31.8 & 69 & 30.1 & 118 & 30.8 \\
\hline No answer & 0 & - & 1 & 0.4 & 1 & 0.3 \\
\hline \multicolumn{7}{|l|}{ Father's education } \\
\hline Primary & 10 & 6.5 & 11 & 4.8 & 21 & 5.5 \\
\hline Middle & 17 & 11.0 & 36 & 15.7 & 53 & 13.8 \\
\hline Intermediate & 39 & 25.3 & 54 & 23.6 & 93 & 24.3 \\
\hline University & 88 & 57.1 & 128 & 55.9 & 216 & 56.4 \\
\hline \multicolumn{7}{|l|}{ Mother's education } \\
\hline Primary & 29 & 18.8 & 35 & 15.3 & 64 & 16.7 \\
\hline Middle & 25 & 16.2 & 43 & 18.8 & 68 & 17.8 \\
\hline Intermediate & 55 & 35.7 & 68 & 29.7 & 123 & 32.1 \\
\hline University & 45 & 29.2 & 82 & 35.8 & 127 & 33.2 \\
\hline No answer & 0 & - & 1 & 0.4 & 1 & 0.3 \\
\hline \multicolumn{7}{|l|}{ Father's occupation } \\
\hline Teacher in school & 9 & 5.8 & 11 & 4.8 & 20 & 5.2 \\
\hline University teacher & 4 & 2.6 & 1 & 0.4 & 5 & 1.3 \\
\hline Engineer & 12 & 7.8 & 15 & 6.6 & 27 & 7.0 \\
\hline Physician & 5 & 3.2 & 8 & 3.5 & 13 & 3.4 \\
\hline Police & 8 & 5.2 & 16 & 7.0 & 24 & 6.3 \\
\hline Clerical and lower grades & 52 & 33.8 & 80 & 34.9 & 132 & 34.5 \\
\hline Lawyer & 2 & 1.3 & 2 & 0.9 & 4 & 1.0 \\
\hline Business & 35 & 22.7 & 60 & 26.2 & 95 & 24.8 \\
\hline Other work & 3 & 1.9 & 6 & 2.6 & 9 & 2.3 \\
\hline Retired & 18 & 11.7 & 25 & 10.9 & 43 & 11.2 \\
\hline Unemployed & 5 & 3.2 & 3 & 1.3 & 8 & 2.1 \\
\hline No answer & 1 & 0.6 & 2 & 0.8 & 3 & 0.8 \\
\hline \multicolumn{7}{|l|}{ Mother's occupation } \\
\hline Teacher school & 34 & 22.1 & 48 & 21.0 & 82 & 21.4 \\
\hline University teacher & 1 & 0.6 & 0 & - & 1 & 0.3 \\
\hline Doctor & 1 & 0.6 & 4 & 1.7 & 5 & 1.3 \\
\hline Other government job & 4 & 2.6 & 3 & 1.3 & 7 & 1.8 \\
\hline Lawyer & 2 & 1.3 & 3 & 1.3 & 5 & 1.3 \\
\hline Other work & 1 & 0.6 & 3 & 1.3 & 4 & 1.0 \\
\hline Retired & - & & 1 & 0.4 & 1 & 0.3 \\
\hline Housewife & 110 & 71.4 & 165 & 72.1 & 275 & 71.8 \\
\hline No answer & 1 & 0.6 & 2 & 0.9 & 3 & 0.8 \\
\hline \multicolumn{7}{|c|}{ No. of earning members at home } \\
\hline$\leq 2$ & 94 & 61.0 & 160 & 69.9 & 254 & 66.3 \\
\hline $3-6$ & 54 & 35.1 & 64 & 27.9 & 118 & 30.8 \\
\hline $7+$ & 6 & 3.9 & 5 & 2.2 & 11 & 2.9 \\
\hline
\end{tabular}




\begin{tabular}{|c|c|c|c|c|c|c|}
\hline \multirow[t]{2}{*}{ Characteristic } & \multicolumn{2}{|c|}{ Males $(n=154)$} & \multicolumn{2}{|c|}{ Females $(n=229)$} & \multicolumn{2}{|c|}{ Total $(n=383)$} \\
\hline & No. & $\%$ & No. & $\%$ & No. & $\%$ \\
\hline \multicolumn{7}{|l|}{ Residential area } \\
\hline Urban area & 22 & 14.3 & 55 & 24.0 & 77 & 20.1 \\
\hline Suburban area & 106 & 68.8 & 148 & 64.6 & 254 & 66.3 \\
\hline Outside Benghazi & 26 & 16.9 & 25 & 10.9 & 51 & 13.3 \\
\hline \multicolumn{7}{|l|}{ Type of residence } \\
\hline Modern villa & 61 & 39.6 & 84 & 36.7 & 145 & 37.9 \\
\hline Apartment & 26 & 16.9 & 55 & 24.0 & 81 & 21.1 \\
\hline Traditional house & 67 & 43.5 & 89 & 38.9 & 156 & 40.7 \\
\hline No answer & 0 & - & 1 & 0.4 & 1 & 0.3 \\
\hline \multicolumn{7}{|l|}{ Type offamily } \\
\hline Nuclear & 92 & 59.7 & 160 & 69.9 & 252 & 65.8 \\
\hline Joint & 62 & 40.3 & 69 & 30.1 & 131 & 34.2 \\
\hline
\end{tabular}

selected by random skipping, using the right hand rule.

\section{Data processing and analysis}

Survey monitoring and data quality assurance process had progressed through scrutinizing, field editing and centralized editing. Analyses were carried out through frequencies and crosstabulations and mean and standard deviation (SD). The chi-squared and Student $t$-tests (independent sample) were used to analyse the significance of differences.

\section{Results}

\section{Sample profile}

The total sample was 383 students: 154 (40.2\%) males and 229 (59.8\%) females. Adolescents (17-19 years) were $30.5 \%$ of the total. A majority of the sample $(68.9 \%)$ were in the earlier years of university education (years 1-2) (Table 1).

Parental educational status showed that more than half of the fathers were educated up to university level (56.4\%) compared with only $33.2 \%$ of mothers. Fathers of male students were more educated than fathers of female students (57.1\% versus $55.9 \%$ ). Proportionately a majority of fathers were in government jobs (clerical grade or lower). The major occupation of mothers was teaching in schools.

More of the students resided in suburban areas (66.3\%) than urban areas (20.1\%) or nearby towns (13.3\%). A majority had 3-6 brothers (53.0\%) and $\leq 2$ sisters (48.0\%). Types of residence were villa (37.9\%), apartment (21.1\%) or house (40.7\%). The number of the wage-earning members at home was $\leq 2$ for $66.3 \%$ of the sample. A nuclear family (one or two generations) was the most common (65.8\%) type of family.

\section{Physical and mental health status}

Most students self-rated their general health as excellent $(43.9 \%)$ or very good (39.4\%); fewer rated it as only good (13.8\%) or poor (2.3\%) (Table 2 ). More males rated their health as excellent than did females ( $47.4 \%$ versus $41.5 \%$ ), while fewer females rated their health as poor than did males ( $1.3 \%$ versus 3.9\%). However, these sex differences were not statistically significant, even when comparing the combined categories excellent/very good versus good/poor.

Age was significantly associated with self-rated health (categorized as excellent/very good versus good/ poor); $92.3 \%$ of those aged $17-19$ years had excellent/very good health versus $79.9 \%$ of those aged $20-24$ years $\left(\chi^{2}=\right.$ $9.12, P=0.003)$.

Of the total sample $17.8 \%$ reported having current health complaints, and there was no significant difference between males and females (18.2\% versus $17.5 \%)$. Among the problems, the most common were digestive problems (19.1\%), flu (13.2\%) and noncommunicable diseases, e.g. high or low blood pressure and diabetes (13.2\%). The major problems among females were digestive problems (22.5\%) and influenza (17.5\%), while among males it was accidents (21.4\%).

There was a significant difference between the sexes in terms of the timing of their last complaint, comparing episodes in the previous 1 month versus more than 1 month and for those who had had an episode of illness in the previous year (Table 2). More females had health problems in the previous month compared with males $\left(\chi^{2}=7.6\right.$, $P=0.006)$.

In the assessment of health status today the most commonly reported concern among the 5 domains was anxiety or depression (described as extreme by $12.5 \%$ of respondents); this rate was much higher among females (17.0\%) than males $(5.8 \%)\left(\chi^{2}=19.3\right.$, $P<0.001)$ (Table 3). Even though few 


\begin{tabular}{|c|c|c|c|c|c|c|c|c|}
\hline \multirow{2}{*}{ Characteristic } & \multicolumn{2}{|c|}{ Males $(n=154)$} & \multicolumn{2}{|c|}{ Females $n=229$ ) } & \multicolumn{2}{|c|}{ Total $(n=383)$} & \multirow[t]{2}{*}{$\chi^{2}$-value } & \multirow[t]{2}{*}{$P$-value } \\
\hline & No. & $\%$ & No. & $\%$ & No. & $\%$ & & \\
\hline \multicolumn{9}{|l|}{ Self-rating of health } \\
\hline Excellent & 73 & 47.4 & 95 & 41.5 & 168 & 43.9 & \multirow{5}{*}{2.087} & \\
\hline Very good & 50 & 32.5 & 101 & 44.1 & 151 & 39.4 & & \\
\hline Good & 24 & 15.6 & 29 & 12.7 & 53 & 13.8 & & $0.149^{b}$ \\
\hline Poor & 6 & 3.9 & 3 & 1.3 & 9 & 2.3 & & \\
\hline No answer & 1 & 0.6 & 1 & 0.4 & 2 & 0.5 & & \\
\hline \multicolumn{9}{|c|}{ Health complaints at present } \\
\hline Yes & 28 & 18.2 & 40 & 17.5 & 68 & 17.8 & \multirow{4}{*}{0.04} & \multirow{4}{*}{0.842} \\
\hline No & 124 & 80.5 & 187 & 81.7 & 311 & 81.2 & & \\
\hline No answer & 2 & 1.2 & 2 & 0.9 & 4 & 1.1 & & \\
\hline Total & 154 & 100.0 & 229 & 100.0 & 383 & 100.0 & & \\
\hline \multicolumn{9}{|l|}{ Diseases at present ${ }^{a}$} \\
\hline Digestive problem & 4 & 14.3 & 9 & 22.5 & 13 & 19.1 & \multirow{12}{*}{2.60} & \multirow{12}{*}{$0.107^{c}$} \\
\hline Influenza & 2 & 7.1 & 7 & 17.5 & 9 & 13.2 & & \\
\hline NCD & 3 & 10.7 & 6 & 15.0 & 9 & 13.2 & & \\
\hline Migraine & 4 & 14.3 & 4 & 10.0 & 8 & 11.8 & & \\
\hline Sensory complaint & 4 & 14.3 & 4 & 10.0 & 8 & 11.8 & & \\
\hline Accident & 6 & 21.4 & 1 & 2.5 & 7 & 10.3 & & \\
\hline Epilepsy & 1 & 3.6 & 2 & 5.0 & 3 & 4.4 & & \\
\hline Depression & 0 & 0.0 & 2 & 5.0 & 2 & 2.9 & & \\
\hline Respiratory problem & 1 & 3.6 & 1 & 2.5 & 2 & 2.9 & & \\
\hline Other & 1 & 3.6 & 0 & 0.0 & 1 & 1.5 & & \\
\hline No answer & 2 & 7.1 & 4 & 10.0 & 6 & 8.9 & & \\
\hline Total & 28 & 100.0 & 40 & 100.0 & 68 & 100.0 & & \\
\hline \multicolumn{9}{|l|}{ Time of last complaint } \\
\hline Previous month & 36 & 34.6 & 81 & 51.9 & 117 & 45.0 & \multirow[t]{3}{*}{7.6} & \multirow[t]{3}{*}{0.006} \\
\hline Other & 68 & 65.4 & 75 & 48.1 & 143 & 55.0 & & \\
\hline Total & 104 & 100.0 & 156 & 100.0 & 260 & 100.0 & & \\
\hline
\end{tabular}

${ }^{a}$ Percentages were calculated out of total diseases reported. ${ }^{b}$ Excellent/very good vs good/poor; ${ }^{\circ}$ Digestive problem/influenza vs all others. $N C D=$ noncommunicable disease, e.g. blood pressure, diabetes.

students reported having extreme pain or discomfort, a large proportion reported moderate pain/discomfort (47.3\%) and this was significantly higher among females (53.7\%) than males (37.7\%) $\left(\chi^{2}=9.59, P=0.008\right)$.

The total mean score for perceived health status today was 72.8 (SD 19.6) (Table 4). Males had significantly better health status than females (75.3 versus 71.2) $(t=2.0, P=0.042)$. Younger students (aged 17-19 years) had better health status than those aged 20-24 years (75.3 versus 71.8), but the difference was not significant.
Health status varied across the faculties. Students in the education faculty scored significantly lower than those in the faculties of pharmacy $(t=2.8, P=$ $0.009)$, engineering $(t=2.1, P=0.043)$, economics $(t=2.3, P=0.023)$, arts $(t=2.0, P=0.052)$ and law $(t=2.4, P=$ $0.022)$. Paternal education positively affected health status; with an increase in educational level there was an increase in health status $(t=-2.4, P=0.017)$ (Table 4). Mothers' education did not show any significant effect. Similarly, children of professionally employed parents (doctors, engineers, schoolteachers, police etc.), both fathers and mothers, had better health status. Those who resided in the city were found to have a lower health status (70.0) than those in suburban areas (73.1) or outside the city (75.6), although this difference was not significant. Family type did not affect health status score.

\section{Emotional health status}

A majority of the sample were in the advanced levels of Dabrowski's theory of emotional functioning (i.e. organized multilevel disintegration), especially the domains of excitation, suggestibility, joy, crying and enthusiasm (more than 30\% of students fell 


\begin{tabular}{|c|c|c|c|c|c|c|c|c|}
\hline \multirow[t]{2}{*}{ Characteristic } & \multicolumn{2}{|c|}{ Males $(n=154)$} & \multicolumn{2}{|c|}{ Females $(n=229)$} & \multicolumn{2}{|c|}{ Total $(n=383)$} & \multirow[t]{2}{*}{$x^{2}$-value } & \multirow[t]{2}{*}{$P$-value } \\
\hline & No. & $\%$ & No. & $\%$ & No. & $\%$ & & \\
\hline \multicolumn{9}{|l|}{ Mobility } \\
\hline No problems & 124 & 80.5 & 171 & 74.7 & 295 & 77.0 & \multirow{3}{*}{3.86} & \multirow{3}{*}{0.145} \\
\hline Some problems & 20 & 13.0 & 29 & 12.7 & 49 & 12.8 & & \\
\hline Confined to bed & 10 & 6.5 & 29 & 12.7 & 39 & 10.2 & & \\
\hline \multicolumn{9}{|l|}{ Self-care } \\
\hline No problems & 143 & 92.9 & 216 & 94.3 & 359 & 93.7 & \multirow{3}{*}{3.00} & \multirow{3}{*}{0.223} \\
\hline Some problems & 9 & 5.8 & 13 & 5.7 & 22 & 5.7 & & \\
\hline Incapable & 2 & 1.3 & 0 & 0.0 & 2 & 0.5 & & \\
\hline \multicolumn{9}{|l|}{ Usual activities } \\
\hline No problems & 100 & 64.9 & 145 & 63.3 & 245 & 64.0 & \multirow{3}{*}{0.45} & \multirow{3}{*}{0.798} \\
\hline Some problems & 47 & 30.5 & 70 & 30.6 & 117 & 30.5 & & \\
\hline Unable & 7 & 4.5 & 14 & 6.1 & 21 & 5.5 & & \\
\hline \multicolumn{9}{|l|}{ Pain or discomfort } \\
\hline None & 88 & 57.1 & 96 & 41.9 & 184 & 48.0 & \multirow{3}{*}{9.59} & \multirow{3}{*}{0.008} \\
\hline Moderate & 58 & 37.7 & 123 & 53.7 & 181 & 47.3 & & \\
\hline Extreme & 8 & 5.2 & 10 & 4.4 & 18 & 4.7 & & \\
\hline \multicolumn{9}{|l|}{ Anxiety or depression } \\
\hline None & 75 & 48.7 & 68 & 29.7 & 143 & 37.3 & \multirow{3}{*}{19.3} & \multirow{3}{*}{$<0.001$} \\
\hline Moderate & 70 & 45.5 & 122 & 53.3 & 192 & 50.1 & & \\
\hline Extreme & 9 & 5.8 & 39 & 17.0 & 48 & 12.5 & & \\
\hline
\end{tabular}

into these domains) and secondary integration, especially the domain of unpleasure (43.3\%) (Table 5). Fewer students were in the lower levels of emotional state (i.e. primary integration and unilevel disintegration), although at primary integration level $35.5 \%$ were in the domain of suicide and at the unilevel disintegration level $47.8 \%$ and $38.4 \%$ fell into the domains of attitude to death and affective memory respectively. More than $30 \%$ of students were in a moderate or confused state of emotion (i.e. spontaneous multilevel disintegration), in the domains of sadness, solitude and suicide.

In emotional-cognitive functioning (Table 5), the primary integration, unilevel disintegration and spontaneous multilevel disintegration levels predominated. More than $30 \%$ of the sample were in the domains of morality and criticism at the primary integration level whereas more than $30 \%$ were in the domains of religious attitude and uncertainty in the unilevel disintegration level.
More than $30 \%$ of students were in the reality and success domains at the spontaneous multilevel disintegration level.

The mean total score was 77.8 (SD 7.3) on emotional status, suggesting that the sample in general remained at the spontaneous multilevel disintegration level (scores between 53 and 78 ), reflecting a period of transition from lower to higher levels (Table 6). There was no significant difference in mean scores by sex or age. However, there were differences in mean scores among faculties; e.g. medicine students scored higher than law students $(t=$ $1.9, P=0.057)$, economics students scored higher than dental $(t=1.8, P=$ $0.080)$, IT $(t=1.8, P=0.079)$ and law students $(t=2.7, P=0.009)$; arts students scored higher than law students $(t=1.8 ; P=0.082)$; education students scored higher than law students $(t=$ $1.84, P=0.070)$. Parental education had no significant effect on emotional development except for those with middle level educated fathers and university educated fathers $(t=-1.87 ; P=0.063)$. Students living in the city area had lower scores than those in suburban areas $(t=$ $1.75 ; P=0.082)$.

\section{Social health status}

\section{Physical activities}

Physical activity was reported by only $34.7 \%$ of the sample, significantly more among males (48.1\%) than females $(25.8 \%)\left(\chi^{2}=19.9, P<0.001\right)$ (Table 7). Physical activities included playing football or any other games (47.3\%), regular walking or jogging (36.8\%), weight lifting (7.5\%), swimming (6.7\%), kung fu or karate (5.2\%), horse riding (4.5\%) and dancing (3.0\%).

\section{Eating habits}

A majority of the sample ate the typical Libyan meal pattern of 3 main meals per day $(59.0 \%)$ rather than only 2 per day (25.3\%); a few students consumed 4 or more meals (Table 7). A 3-meal system was more prevalent among males, whereas a 2-meal system was 


\begin{tabular}{|c|c|c|}
\hline \multicolumn{3}{|c|}{$\begin{array}{l}\text { Table } 4 \text { Mean scores on self-perceived health status today } \\
\text { index of students in Benghazi }(n=383)\end{array}$} \\
\hline Characteristic & No. & Mean score (SD) \\
\hline \multicolumn{3}{|l|}{ Sex } \\
\hline Male & 154 & $75.3(18.1)$ \\
\hline Female & 229 & $71.2(20.4)$ \\
\hline \multicolumn{3}{|l|}{ Age (years) } \\
\hline $17-19$ & 117 & $75.3(17.7)$ \\
\hline $20-24$ & 266 & $71.8(20.3)$ \\
\hline \multicolumn{3}{|l|}{ Year of study } \\
\hline $1-2$ & 264 & 73.5 (19.6) \\
\hline $3+$ & 118 & $71.4(19.7)$ \\
\hline No answer & 1 & $70.0(19.6)$ \\
\hline \multicolumn{3}{|l|}{ Faculty } \\
\hline Medicine & 40 & $72.0(18.8)$ \\
\hline Dentistry & 16 & $75.5(15.3)$ \\
\hline Pharmacy & 15 & $82.3(13.3)$ \\
\hline Public health & 10 & $77.0(14.9)$ \\
\hline Nursing & 3 & $43.3(45.0)$ \\
\hline Engineering & 41 & $74.6(18.1)$ \\
\hline Science & 63 & $70.6(21.1)$ \\
\hline Economics & 88 & $74.5(18.6)$ \\
\hline Arts & 59 & $72.7(16.8)$ \\
\hline Education & 18 & $62.7(24.4)$ \\
\hline Law & 22 & $78.4(16.7)$ \\
\hline IT & 8 & $58.7(34.8)$ \\
\hline \multicolumn{3}{|c|}{ Father's education } \\
\hline Primary & 21 & $69.7(20.8)$ \\
\hline Middle & 53 & $71.7(17.4)$ \\
\hline Intermediate & 93 & $69.1(21.5)$ \\
\hline University & 216 & $75.0(18.9)$ \\
\hline \multicolumn{3}{|c|}{ Mother's education } \\
\hline Primary & 64 & $70.0(23.2)$ \\
\hline Middle & 68 & $72.2(20.0)$ \\
\hline Intermediate & 123 & 73.5 (18.4) \\
\hline University & 127 & $73.8(18.7)$ \\
\hline No answer & 1 & $80.0(-)$ \\
\hline
\end{tabular}

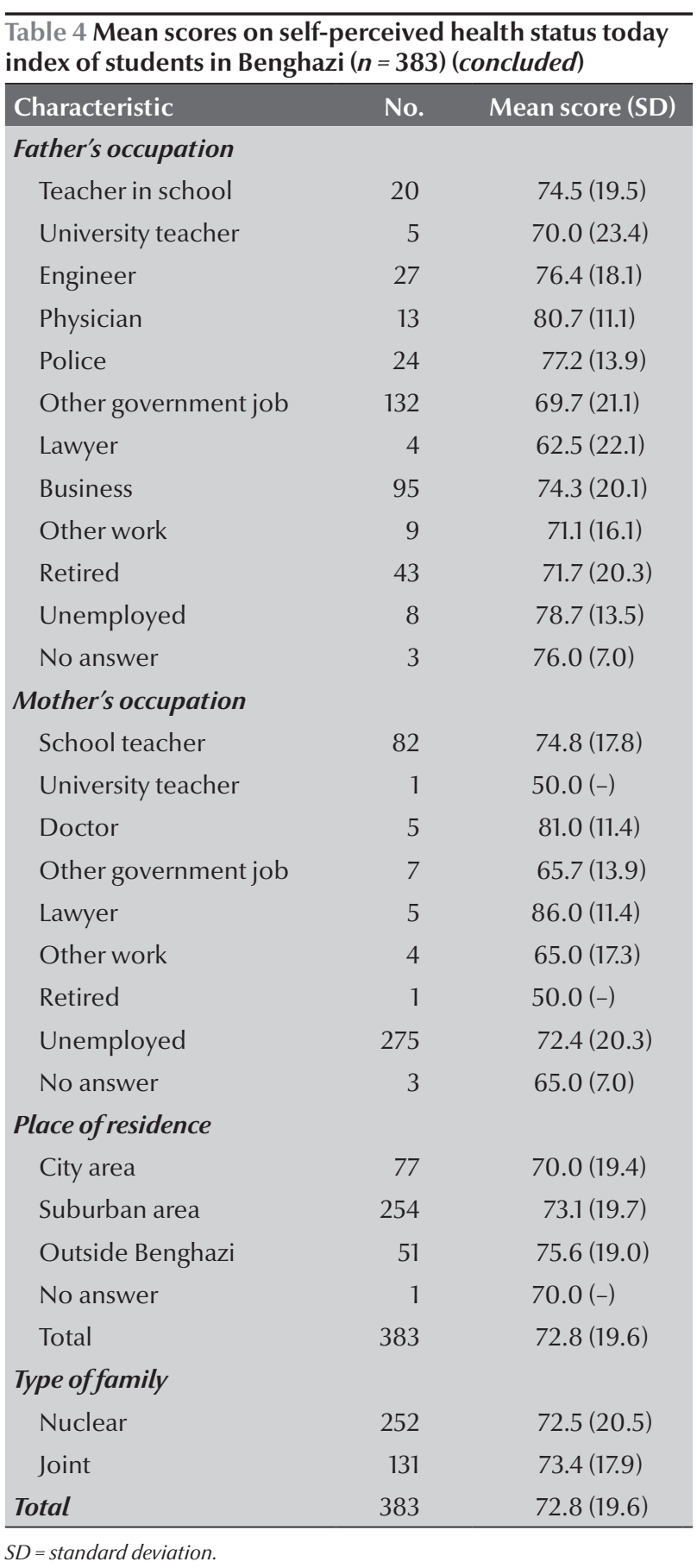

more prevalent among females. Eating out in restaurants was a common practice among the sample (63.2\%). Fresh juice was the preferred drink, followed by soft drinks and coffee.

\section{Social activities}

Visiting relatives was the main social activity among $77.8 \%$ of students, more commonly among females (81.2\%) than males (72.7\%) (Table 7). Of the males $11.7 \%$ had no social activities and $11.0 \%$ reported just wandering around as their main activity.

\section{Substance use}

More than one-third of the males in the sample reported that they smoked (36.4\%) compared with $4.4 \%$ of the females. A few students admitted to alcohol (5.0\%) and narcotic drug use (4.2\%).

\section{Discussion}

The current study explored the physical, social and mental health status of a sample of students aged 17-24 years which was drawn from 2 universities located in the city of Benghazi. Attempts were made to link some of the independent variables with health status variables. 
ஸें

ลิ

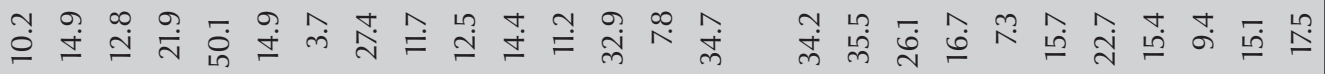

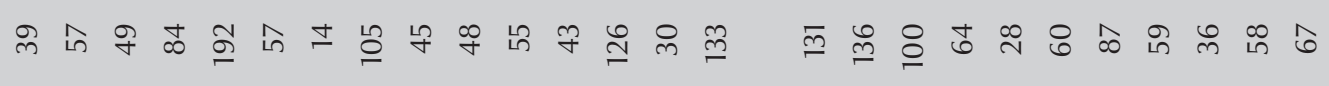

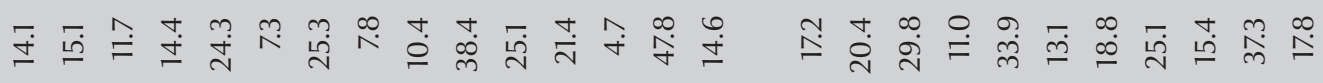

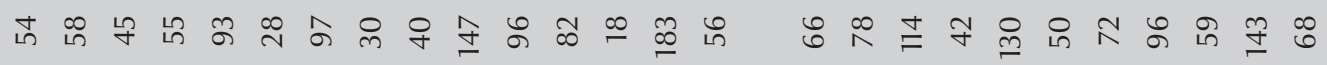
仓் ப் 万எ

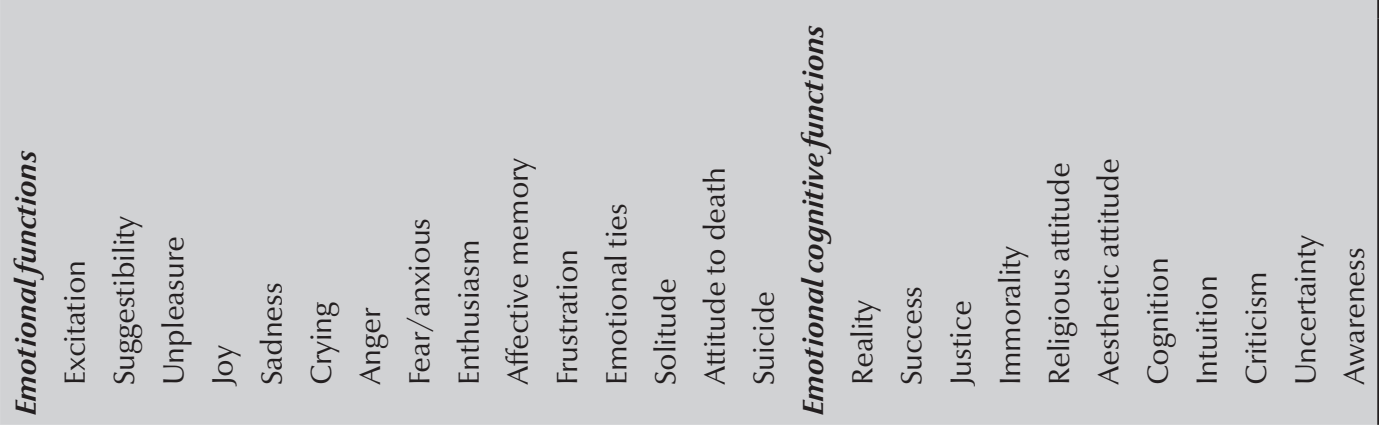




\begin{tabular}{|c|c|c|}
\hline \multicolumn{3}{|c|}{$\begin{array}{l}\text { Table } 6 \text { Means score on emotional development index of } \\
\text { students in Benghazi }(n=383)\end{array}$} \\
\hline Variable & No. & Mean score (SD) \\
\hline \multicolumn{3}{|l|}{ Sex } \\
\hline Male & 154 & $77.7(7.2)$ \\
\hline Female & 229 & 77. $8(7.3)$ \\
\hline \multicolumn{3}{|l|}{ Age (years) } \\
\hline 17-19 & 117 & $77.3(7.3)$ \\
\hline $20-24$ & 266 & $78.0(7.3)$ \\
\hline \multicolumn{3}{|l|}{ Year of study } \\
\hline $1-2$ & 264 & $77.7(7.4)$ \\
\hline $3+$ & 118 & $77.9(7.0)$ \\
\hline No answer & 1 & $78.0(-)$ \\
\hline \multicolumn{3}{|l|}{ Faculty } \\
\hline Medicine & 40 & $78.1(5.9)$ \\
\hline Dentistry & 16 & $75.8(7.5)$ \\
\hline Pharmacy & 15 & $76.2(7.2)$ \\
\hline Public health & 10 & $77.5(8.0)$ \\
\hline Nursing & 3 & $77.0(14.4)$ \\
\hline Engineering & 41 & $78.1(8.2)$ \\
\hline Science & 63 & $77.5(7.7)$ \\
\hline Economics & 88 & $79.1(6.8)$ \\
\hline Arts & 59 & $77.7(6.5)$ \\
\hline Education & 18 & $79.3(7.8)$ \\
\hline Law & 22 & $74.6(8.2)$ \\
\hline $\mathrm{IT}$ & 8 & $74.6(7.6)$ \\
\hline \multicolumn{3}{|l|}{ Place of residence } \\
\hline City area & 77 & $76.4(7.5)$ \\
\hline Suburban area & 254 & $78.1(7.2)$ \\
\hline Outside Benghazi & 51 & $77.9(7.1)$ \\
\hline No answer & 1 & $92.0(-)$ \\
\hline
\end{tabular}

\begin{tabular}{|c|c|c|}
\hline Variable & No. & Mean score (SD) \\
\hline \multicolumn{3}{|l|}{ Father's occupation } \\
\hline School teacher & 20 & $79.4(8.2)$ \\
\hline University teacher & 5 & $76.8(8.0)$ \\
\hline Engineer & 27 & $78.0(5.8)$ \\
\hline Physician & 13 & $72.5(3.9)$ \\
\hline Police & 95 & $79.0(7.5)$ \\
\hline Other government job & 24 & $78.7(8.1)$ \\
\hline Lawyer & 132 & $77.6(7.6)$ \\
\hline Business & 43 & $75.8(6.3)$ \\
\hline Other work & 8 & $73.9(7.4)$ \\
\hline Retired & 4 & $77.2(6.7)$ \\
\hline Unemployed & 9 & $79.2(4.7)$ \\
\hline No answer & 3 & $84.0(1.4)$ \\
\hline \multicolumn{3}{|l|}{ Mother's occupation } \\
\hline School teacher & 82 & $77.6(7.3)$ \\
\hline University teacher & 1 & $73.0(-)$ \\
\hline Physician & 5 & $72.0(7.3)$ \\
\hline Other government job & 7 & $79.4(6.5)$ \\
\hline Lawyer & 1 & $77.0(-)$ \\
\hline Other work & 275 & $77.8(7.3)$ \\
\hline Retired & 5 & $78.8(8.6)$ \\
\hline Unemployed & 4 & $80.0(8.4)$ \\
\hline No answer & 3 & $80.5(7.8)$ \\
\hline \multicolumn{3}{|l|}{ Type offamily } \\
\hline Nuclear & 252 & $77.3(7.3)$ \\
\hline Joint & 131 & $78.6(7.2)$ \\
\hline Total & 383 & $77.8(7.3)$ \\
\hline
\end{tabular}

$S D=$ standard deviation .

\section{Profile of sample}

Proportionate sampling meant that there were more females than males in the sample. This was not only proportional to the existing sex composition at these universities but also of medical universities in nearby Arab countries $[13,14]$. Parental profile showed that a large majority were from the upper middle class group with highly educated fathers and mothers in addition to higher parental occupational levels. The higher socioeconomic status of university level students has been demonstrated elsewhere in the Eastern Mediterranean region $[13,14]$. More students resided in suburban areas, which might be because of the emergence of new residential areas as a result of increasing urbanization in Benghazi [8]. They were mostly from moderate family backgrounds in terms of family size, type of housing and type of family and this agrees with the profile of students of other countries $[6,7,13]$.

\section{General health status}

Health as a "state of complete physical, mental and social well being and not merely the absence of disease or infirmity" $[15]$ was examined in this study from 3 dimensions. Physically and mentally, this group had moderately high rating of their own health. Self-rating of health and self-reports of present complaints/ diseases did not vary significantly by sex or by age. Similarities in health complaints between males and females and between adolescents and youths have been shown before $[1,16]$. Although the types of illnesses did not vary between the sexes the frequency of illness episodes, however, had an association with sex. Among females, a higher proportion had health problems in the previous month compared with males. Sex differences in physical functioning among adolescents have been shown before [17].

Variables developed to assess health status today brought similar results for males and females in terms of mobility, 


\begin{tabular}{|c|c|c|c|c|c|c|}
\hline \multirow[t]{2}{*}{ Variable } & \multicolumn{2}{|c|}{$\begin{array}{c}\text { Males } \\
(n=154)\end{array}$} & \multicolumn{2}{|c|}{$\begin{array}{l}\text { Females } \\
(n=229)\end{array}$} & \multicolumn{2}{|c|}{$\begin{array}{c}\text { Total } \\
(n=383)\end{array}$} \\
\hline & No. & $\%$ & No. & $\%$ & No. & $\%$ \\
\hline \multicolumn{7}{|l|}{ Physical activity } \\
\hline Yes & 74 & 48.1 & 59 & 25.8 & 133 & 34.7 \\
\hline No & 80 & 51.9 & 169 & 73.8 & 249 & 65.0 \\
\hline No answer & 0 & - & 1 & 0.4 & 1 & 0.3 \\
\hline \multicolumn{7}{|c|}{ No. of primary meals/day } \\
\hline 1 & 4 & 2.6 & 12 & 5.2 & 16 & 4.2 \\
\hline 2 & 33 & 21.4 & 64 & 27.9 & 97 & 25.3 \\
\hline 3 & 100 & 64.9 & 126 & 55.0 & 226 & 59.0 \\
\hline $4+$ & 17 & 11.0 & 27 & 11.7 & 44 & 11.5 \\
\hline \multicolumn{7}{|c|}{ Meals from restaurants/day } \\
\hline 0 & 57 & 37.0 & 84 & 36.7 & 141 & 36.8 \\
\hline 1 & 77 & 50.0 & 122 & 53.3 & 199 & 52.0 \\
\hline 2 & 18 & 11.7 & 17 & 7.4 & 35 & 9.1 \\
\hline $3+$ & 2 & 1.3 & 6 & 2.6 & 8 & 2.0 \\
\hline \multicolumn{7}{|l|}{ Usual drinks } \\
\hline Coffee & 45 & 29.2 & 56 & 24.5 & 101 & 26.4 \\
\hline Tea & 14 & 9.1 & 13 & 5.7 & 27 & 7.0 \\
\hline Soft drinks & 45 & 29.2 & 58 & 25.3 & 103 & 26.9 \\
\hline Fresh juice & 50 & 32.5 & 100 & 43.7 & 150 & 39.2 \\
\hline No answer & 0 & - & 2 & 0.9 & 2 & 0.5 \\
\hline \multicolumn{7}{|l|}{ Usual social activities } \\
\hline None & 18 & 11.7 & 4 & 1.7 & 22 & 5.7 \\
\hline Wandering around & 17 & 11.0 & 17 & 7.4 & 34 & 8.9 \\
\hline Charity work & 0 & - & 3 & 1.3 & 3 & 0.8 \\
\hline Visiting relatives & 112 & 72.7 & 186 & 81.2 & 298 & 77.8 \\
\hline No answer & 7 & 4.5 & 19 & 8.3 & 26 & 6.8 \\
\hline \multicolumn{7}{|l|}{ Smoking } \\
\hline Yes & 56 & 36.4 & 10 & 4.4 & 66 & 17.2 \\
\hline No & 98 & 63.6 & 219 & 95.6 & 317 & 82.8 \\
\hline \multicolumn{7}{|l|}{ Alcohol use } \\
\hline Yes & 18 & 11.7 & 1 & 0.4 & 19 & 5.0 \\
\hline No & 136 & 88.3 & 227 & 99.1 & 363 & 94.8 \\
\hline No answer & 0 & - & 1 & 0.4 & 1 & 0.3 \\
\hline \multicolumn{7}{|l|}{ Narcotic drug use ${ }^{a}$} \\
\hline Yes & 2 & 7.8 & 4 & 1.7 & 16 & 4.2 \\
\hline No & 142 & 92.2 & 224 & 97.8 & 366 & 95.6 \\
\hline No answer & 0 & - & 1 & 0.4 & 1 & 0.3 \\
\hline
\end{tabular}

aIncludes chewing drugs (marijuana, khat, hashish) and injecting drugs.

self-care and usual activities, with a large majority having no inabilities or problems. In the areas of pain/discomfort and anxiety/depression, however, there was a significant difference between the sexes, with females reporting these more frequently. This imbalance against females is an area for further investigation and intervention $[16,18,19]$. At higher ages there was higher self-reported disability on both the variables of mobility and pain/discomfort. Age differentials in perceived health have been shown previously [10] and studies have found depression among school children [18].

The mean scores for health status today also revealed that the population as a whole had good perceived health 
and that males had better self-perceived health than females. While age or university or year of study did not show much variation there were differences in perceived health score across faculty. It might be assumed that the faculty to which students belong represents social class differences. Parental education influenced the students' perceived health. Children of fathers of intermediate and university level had significantly better perceived health status but mothers' education did not produce any significant difference. These findings contradict the popular notion that maternal education is more important in family health $[10,16,20]$. There were no differentials in perceived health levels between rural and urban residence or nuclear versus joint family, again contradicting other findings $[10,16]$.

Emotional health, as measured according to Dabrowski's emotional development theory, showed that the students were going through a transitional stage from the primary to secondary levels. A majority of the group were going through the transitional stage of spontaneous multilevel disintegration in terms of both emotional functions and emotional-cognitive functions. Both males and females followed similar patterns of emotional development, which was in agreement with other research hypotheses [10,11]. Neither sex nor age group made a significant difference to overall emotional levels. Faculty of study was a distinguishing variable in terms of emotional health, perhaps because faculties represent varying levels of socioeconomic status. This draws attention to the need to consider adolescents' and youth's issues separately by considering their heterogeneity [20,21], offering space for achievement of emotional independence, attaining economic independence, coming in terms with sexuality and achievement of ego identity [22]. Parental education had no significant effect on emotional development, except for students with middle level educated fathers and university educated fathers. Students living in the city area differed significantly from those from suburban areas.

Social health, explored through a number of variables such as physical activities, eating habits, social engagements and substance abuse, revealed inactivity by a large proportion of students, over-eating by some, no social engagements by a few and substance use by very few. More females than males were physically inactive. Libyan society has close family ties and for more than three-fifths of students family visits were the major social activity. One-fifth of males had no social activities and or reported "wandering around" as an activity. Cigarettes are widely available and smoking is socially acceptable in Libyan society, especially for males. There was an early age at onset of smoking habit. Alcohol is not socially sanctioned and only 5.0\% of students (all except 1 were males) reported drinking and slightly fewer were narcotic drug users.

There were some limitations of the current study. It was carried out in only 2 universities in Benghazi, which limits the results to a certain social strata. The study used tools that were developed in other cultural contexts, which is also a limitation.

\section{Conclusions}

The study highlights some concerns about physical health status in terms of mobility, self-care, inability to conduct usual activities and mental health in terms of depression and anxiety, especially among women. Emotional health was at a transitional stage. Lifestyle variables showed that smoking and low levels of physical activity, especially among women, need to be addressed. Education programmes are needed for young people at university level in Libya on balanced nutrition and lifestyle modifications. Counselling programmes may be useful to equip students with better life coping skills to deal with stressful situations.

\section{References}

1. Hobson W. The theory and practice of public health. New York, Oxford University Press, 1979.

2. Chandra-Mouli V, Lawe-Davies O, Dick B. Responding to the needs of adolescents. Bulletin of the World Health Organization, 2010, 88:3-4.

3. Social cohesion for mental well-being among adolescents. WHO/ HBSC Forum 2007. Copenhagen, World Health Organization Regional Office for Europe, 2008.

4. Franz MA. By providing a platform for terrorist, the UN raises the question: does it belong in the US? Heritage Foundation Executive Memorandum No. 220, 1 December 1988.

5. Adolescent health services: missing opportunities. Report brief. December 2008. Washington DC, National Academies Press, 2008.

6. Murthy L. Transition for whom? Adolescence theories with androcentric bias. Sex Roles, 1978, 14:369-375.
7. Hewett PC. Measuring the impact of school quality on adolescent girls and boys educational outcomes in rural Malawi. Paper presented at the Comparative and International Education Society Conference, New York, 17-21 March 2008. New York, Hewlett Foundation and Population Council, 2008.

8. Statistical book 2008. Tripoli, General Authority for Information, 2008.

9. Sample size calculator. Raosoft ${ }^{\circledast}$ [website] (www.ezsurvey. com/samplesize.html, last accessed 27 March 2012).

10. Kind $\mathrm{P}$ et al. Variations in population health status: results from a United Kingdom national questionnaire survey. British Medical Journal, 1998, 316:736-741.

11. Chang YP. Overexcitabilities and emotional developmental levels of mathematical-logic gifted students in senior high schools in northern Taiwan, ROC. Paper presented at the 8th Asia-Pacific Conference on Giftedness. Daejeon, Korea, 26-30 July 2004. 
12. Dabrowski K, Piechowski MM. Theory of levels of emotional development Oceanside, New York, Dabor Sceince, 1977.

13. Abalkhail B. Overweight and obesity among Saudi Arabian children and adolescents between 1994 and 2000. Eastern Mediterranean Health Journal, 2002, 8:470-479.

14. Abou-Zeid AH, Hifnawy TM, Abdel Fattah M. Health habits and behaviour of adolescent schoolchildren, Taif, Saudi Arabia. Eastern Mediterranean Health Journal, 2009, 15:1525-1534.

15. Declaration of Alma Ata. International Conference on Primary Health Care. Alma Ata, USSR 6-12 September 1978. (http:// www.who.int/hpr/NPH/docs/declaration_almaata.pdf, last accessed 27 March 2012).

16. Kumar R, Prinja S, Lakshmi PV. Health care seeking behavior of adolescents: comparative study of two service delivery models. Indian Journal of Pediatrics, 2008, 75:895-899.

17. Jago R et al. Adolescent patterns of physical activity differences by gender, day, and time of day. American Journal of Preventive Medicine, 2005, 28:447-452.
18. Kimber B, Sandell R, Bremberg S. Social and emotional training in Swedish classrooms for the promotion of mental health: results from an effectiveness study in Sweden. Health Promotion International, 2008, 23:134-143.

19. Rao U. Links between depression and substance abuse in adolescents. American Journal of Preventive Medicine, 2006, 31(6S1):161-164.

20. Country cooperation strategy for WHO and the Libyan Arab Jamahiriya 2005-2009. Cairo, World Health Organization Regional Office for the Eastern Mediterranean, 2006.

21. Regional Health Systems Observatory. Health system profile. Libya. Cairo World Health Organization Regional Office for the Eastern Mediterranean, 2007.

22. Vingo FJ. Clinical psychology and medicine: an interdisciplinary approach. New York, Oxford Medical Publications, 1981:41-44.

\section{Correction}

E. Alkhasawneh, L. Ismayilova, H. Olimat and N. El-Bassel. Social and behavioural HIV/AIDS research in Jordan: a systematic review. Eastern Mediterranean Health Journal, 2012, 18(5):487-494. The name of the author H. Olimat in Arabic should read: عليمات وليس غليم. 